\title{
Myxosporidiosis in intensively-reared Piaractus mesopotamicus: Histopathological diagnosis by means of Ziehl-Neelsen staining ${ }^{1}$
}

\author{
Wilson G. Manrique², Gustavo S. Claudiano², Mayra A.P. Figueiredo², Thalita R. Petrillo³, \\ Julieta R.E. Moraes ${ }^{3}$ and Flávio R. de Moraes $^{3 *}$
}

\begin{abstract}
Manrique W.G., Claudiano G.S., Figueiredo M.A.P., Petrillo T.G., Moraes J.R.E. \& Moraes F.R. 2012. Myxosporidiosis in intensively-reared Piaractus mesopotamicus: Histopathological diagnosis by means of Ziehl-Neelsen staining. Pesquisa Veterinária Brasileira 32(11):1133-1137. Laboratório de Ictiopatologia, Departamento de Patologia Animal, Faculdade de Ciências Agrárias e Veterinárias, Universidade Estadual Paulista, Campus de Jaboticabal, Via de acesso Prof. Paulo Donato Castellane s/n, Jaboticabal, SP 14884-900, Brazil. E-mail: fruasmoraes@gmail.com

Samples of different organs from intensively-reared Piaractus mesopotamicus were collected and processed using routine histological techniques in order to produce thin sections for staining with hematoxylin-eosin and with the Ziehl-Neelsen method. Through examination under an optical microscope, myxosporidians of the genera Henneguya sp. and Мухоbolus sp. were identified, respectivelyin the gills and kidneys of $P$. mesopotamicus. Plasmodia with immature spores of Henneguya sp. were located along the secondary lamellae, with total length of $30.45 \pm 4.84 \mu \mathrm{m}$ and width of $3.52 \pm 0.33 \mu \mathrm{m}$. Spores of Myxobolus sp. were located in the kidneys, with total length of $8.94 \pm 0.82 \mu \mathrm{m}$ and width of $5.59 \pm 0.39 \mu \mathrm{m}$. Histopathological analysis of the gills showed plasmodia containing spores of Henneguya sp., at intralamellar and intravascular localities, at different stages of development. Spores of Myxobolus sp. were identified in the kidneys, in the peritubular region and in the interstices and glomerulus, surrounded by melanomacrophages. Focal hemorrhage was recorded in a few cases. Ziehl-Neelsen staining allowed to identify particular features of the spores and facilitated biometry and enabled classification in comparison with hematoxylin-eosin, thus demonstrating its usefulness for histopathological diagnosis of the parasitosis.
\end{abstract}

INDEX TERMS: Pacu, fish, parasite, Henneguya sp., Myxobolus sp.

RESUMO.-[Mixosporidiose em Piaractus mesopotamicus de criação intensiva: diagnóstico histopatológico pela coloração Ziehl-Neelsen.] Amostras de diferentes órgãos de Piaractus mesopotamicus mantidos em criação intensiva foram coletadas e processadas mediante as técnicas histológicas usuais para obtenção de cortes que foram corados com hematoxilina-eosina e pelo método de Ziehl-Neelsen. Ao exame em microscopia de luz foi possível identificar mixosporídeos dos gêneros Henneguya sp. e Myxobolus sp. em brânquia e rim de P. mesopotamicus res-

\footnotetext{
${ }^{1}$ Received on May 15, 2012.

Accepted for publication on August 9, 2012.

${ }^{2}$ Laboratório de Ictiopatologia, Departamento de Patologia Veterinária, Faculdade de Ciências Agrárias e Veterinárias (FCAV), Universidade Estadual Paulista (Unesp), Campus de Jaboticabal, Via de acesso Prof. Paulo Donato Castellane s/n, Jaboticabal, SP 14884-900, Brazil. *Corresponding autor: fruasmoraes@gmail.com

${ }^{3}$ Departamento de Patologia Animal, FCAV-Unesp, Jaboticabal, SP.
}

pectivamente. Plasmódios com esporos imaturos de Henneguya sp. foram localizados ao longo das lamelas secundárias e mensurados (comprimento total $30,45 \pm 4,84 \mu \mathrm{m}$ e largura 3,52 $\pm 0,33 \mu \mathrm{m}$ ) e no rim esporos de Myxobolus sp. (comprimento total $8,94 \pm 0,82 \mu \mathrm{m}$ e largura $5,59 \pm 0,39 \mu \mathrm{m}$ ). $\mathrm{Na}$ análise histopatológica das brânquias observaram-se plasmódios contendo esporos de Henneguya sp., com localização intralamelar e intravascular, em diferentes estágios de desenvolvimento. No rim identificaram-se esporos de Myxobolus sp., na região peritubular e no interstício e glomérulo, circundados por melanomacrófagos. Em poucos casos foi registrada hemorragia focal. 0 uso da coloração de Ziehl-Neelsen permitiu identificar particularidades dos esporos, facilitou sua biometria e classificação em comparação com a hematoxilina-eosina, demonstrando sua utilidade no diagnóstico histopatológico da referida parasitose. TERMOS DE INDEXAÇÃO: Pacu, parasitos de peixe, Henneguya sp., Myxobolus sp. 


\section{INTRODUCTION}

Protozoa of the phylum Myxozoa (myxosporidians) are among the main pathogens of freshwater and saltwater fish. They are found in many organs, cause damage to the host and have a negative impact on fish farming (Sardella et al. 1987, Casal et al. 1996, Moraes \& Martins, 2004, Eszterbauer et al. 2006). These parasites may have intracellular locations, in which case they are called celozoic, or extracellular locations, in which case they are called histozoic. Celozoic parasites live freely in organ cavities, while histozoic parasites are located inside cells, in intercellular matter or in the lumen of blood vessels. Their main hosts are aquatic vertebrates, although they may also parasitize invertebrates, and their pathogenicity is related mainly to the cystic lesions that they produce in their hosts (Lom \& Dyková, 1992). According to Eszterbauer et al. (2006), 52 genera and 1350 species of parasites in the phylum Myxozoa affect fish, with a high degree of morphological variability of spores within the same species and simplified body shape.

Among the myxosporidians that cause most harm to teleost fish reared in captivity in Brazil are the genera Henneguya and Myxobolus (Martins et al. 1997, 2000, 2002, Martins et al. 1999a,b, Moraes \& Martins 2004, Schalch \& Moraes 2005).

Currently, these parasites are identified under the microscope by means of Giemsa staining (Meyers et al. 1977) and with Lugol's solution and May-Grünwald-Giemsa staining for observations on fresh specimens; while for histopathological examination, hematoxylin-eosin staining is used. These techniques together make it possible to view plasmodia and spores and determine morphometric parameters (Martins et al. 2000, 2002, Tavares-Dias et al. 2001, Schalch \& Moraes, 2005, Campos et al. 2008, 2011).

According to Lom \& Noble (1984), identification of these parasites is based on the morphology of the spores, with emphasis on the morphology and morphometry of the polar capsules and on aspects of the flagella.

Ziehl-Neelsen (ZN) staining delineates the cell walls of acid-alcohol resistant bacilli (AARB). This structure contains $\mathrm{N}$-glycolylmuramic acid, and around $60 \%$ consists of lipids formed by long-chain fatty acids with 60 to 90 carbon atoms, named mycolic acids. These are covalently bonded to the polysaccharide arabinogalactan, which in turn bonds to the peptide glycan. The cell wall also contains other free lipids that are unassociated with the basal framework of the membrane, and some proteins (Ducati et al. 2005). Because of the high lipid content of mycobacterial cell walls, they stain red when treated with phenicated fuchsine, and this persists when stain-removing strong acid-alcohol solutions are subsequently applied. This constitutes a differentiator.

In evaluating lesions caused by mycobacteria in pacus, Piaractus mesopotamicus, other structures within the tissues and organs that acquired red staining in histological thin sections stained using ZN were also observed. The present study was conducted with the aim of identifying these structures at genus level, which are frequently present in the tissues of $P$. mesopotamicus, and assessing the histological damage

\section{MATERIALS AND METHODS}

Young male and female specimens of Piaractus mesopotamicus $(\mathrm{n}=60)$, of mean weight $120 \pm 5.0 \mathrm{~g}$, were caught during the month of October (dissolved oxygen $5.03 \mathrm{mg} / \mathrm{L}$; temperature $29.47^{\circ} \mathrm{C}$; $\mathrm{pH}$ 7.66; and conductivity $117.96 \mu \mathrm{S} / \mathrm{cm}$ ), in an intensive rearing system, in the northeastern region of the state of São Paulo. The fish were sacrificed by means of benzocaine $(1: 500 \mathrm{v} / \mathrm{v})$ and were then necropsied. Pieces of the gills, kidneys, spleen and liver were collected for histopathological examination. These specimens were fixed in Bouin's solution for 12 hours and then underwent the routine procedure for obtaining paraffin-block sections of thickness $3 \mu \mathrm{m}$. These were stained using hematoxylin-eosin (HE) and the Ziehl-Neelsen (ZN) method, followed by examination under an optical microscope (Olympus CX51) and image capture using an Olympus DP72 camera at magnifications of 40,100, 200, 400 and 1000x. Measurements on the images were made with the aid of the Olympus cellSens v. 2.1 software. A total of 510 spores were measured.

\section{RESULTS}

From a total of 60 examined fish, $54(90 \%)$ were infected by Henneguya sp., 57 (95\%) by Myxobolus sp. and 46 (76,6\%) by Henneguya sp. and Myxobolus sp. Examination of the slides stained with HE revealed the presence of structures similar to plasmodia, of varying sizes and with amorphous content, located in the pacus' gills. Some sinusoids presented congestion, telangiectasia in secondary lamellae and hyperplasia of cells in the gill-coating epithelium. In the secondary lamellae, subepithelial edema and intraepithelial and intravascular plasmodia were observed. The larger plasmodia occupied the entire lamella, thereby causing dilatation of the sinusoid and lamella, and in some cases, also deforming the neighboring lamellae through compression. Intravascular plasmodia caused congestion. In some regions, the hyperplasia of the coating epithelium filled the interlamellar space, consequently causing fusion of the neighboring lamellae and scaling of the epithelium. The presence of plasmodia caused dilatation of the lamellae and interlamellar hyperplasia, thus changing the gill architecture (Fig.1).

The slides containing sections through the gills stained with ZN presented plasmodia in various stages of development, located along the primary lamellae. The ZN staining made it possible to view spores that presented two polar capsules, a red body and a transparent red polar filament originating in the polar capsule (Fig.2). Although these structures were differentiated, it was not possible to measure the polar capsules (Table 1).

In the kidneys, agglomerations of melanomacrophages and slight focal hemorrhage were seen to be present in the midst of the tubules and glomeruli. The renal tubules presented cellular edema in the epithelial coating, with diminished lumen size and, in the glomeruli, the Bowman space was smaller and the glomerular tuft showed greater cellularity. This was a condition compatible with glomerular nephritis, in the regions where the numbers of parasites were greater, as confirmed by the ZN staining (Fig.3).

In kidney sections stained with $\mathrm{ZN}$, spores were found to be located mainly in the peritubular interstitial tissue and, rarely, in the glomeruli. The spores contained two po- 


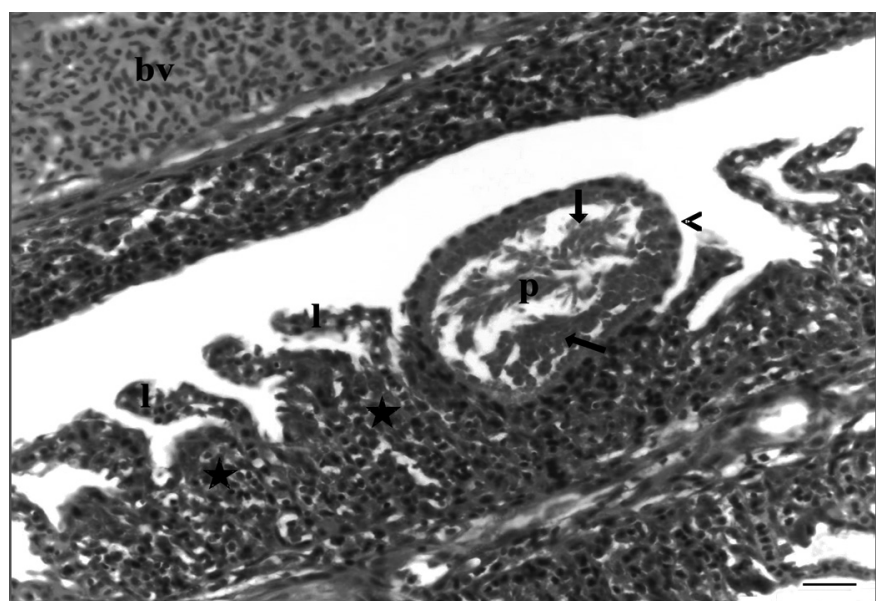

Fig.1. Gills of Piaractus mesopotamicus. Note plasmodium (p) containing large numbers of spores of Henneguya sp. (arrow), inside the secondary lamella, which can be seen to be thickened (arrowhead) in comparison with the normal secondary lamella (1); interlamellar hyperplasia (star); and, at the top of the photo, a blood vessel (bv). HE. Bar $=20 \mu \mathrm{m}$.

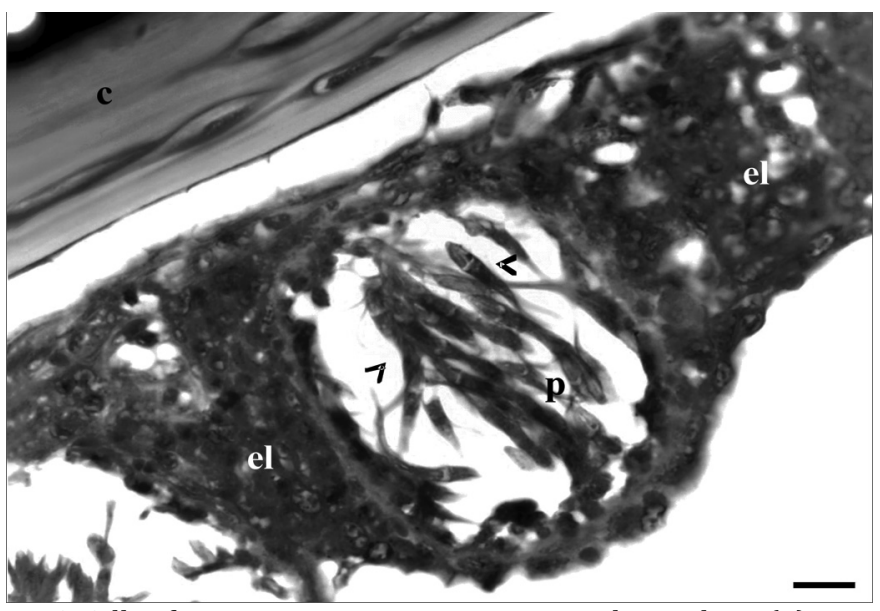

Fig.2. Gills of Piaractus mesopotamicus. Note plasmodium (p) containing spores of Henneguya sp. (arrowhead), lamellar hyperplasia (el) and gill cartilage (c). ZN, Bar $=10 \mu \mathrm{m}$.

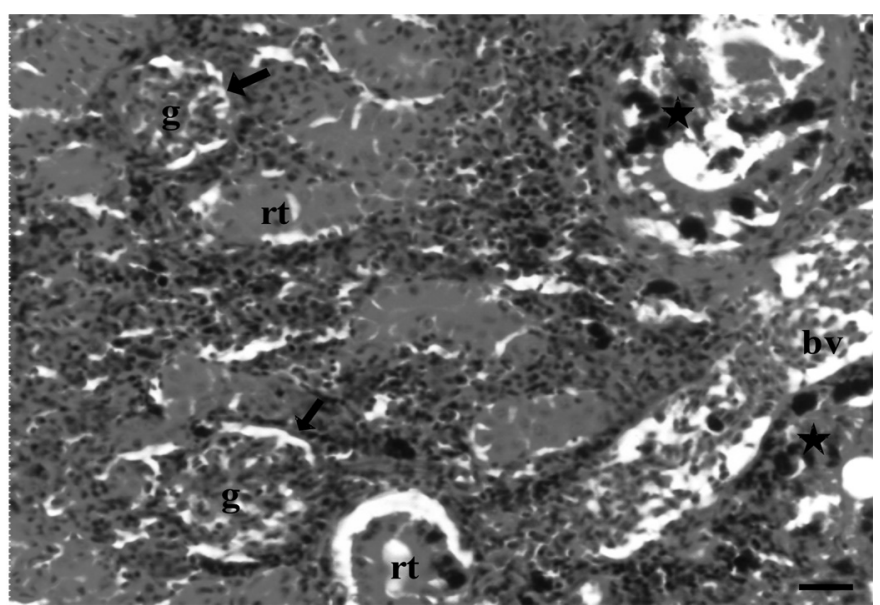

Fig.3. Kidney of Piaractus mesopotamicus. Note glomerulus (g), reduction of Bowman space (arrow), renal tubules (rt) and agglomerations of melanomacrophages (star) Blood vessel (bv). HE. Bar $=20 \mu \mathrm{m}$. lar capsules that were stained red, spore plasma of light red color, the body stained transparent red and a thin red membrane that formed the boundary between the spore and the interstitial tissue that contained it. This characteristic facilitated measurement of the spore (Table 1). However, these spores did not present a polar filament (Fig.4).

Table 1.Morphometry (in $\mu \mathrm{m} \pm$ standard deviation and the number of structures measured in parenthesis) of Henneguya sp. and Myxobolus sp. spores found in Piaractus mesopotamicus

\begin{tabular}{lcc}
\hline \multicolumn{1}{c}{ Description } & Henneguya sp. & Myxobolus sp. \\
\hline Spore length & $30.45 \pm 4.84(227)$ & $8.94 \pm 0.82(283)$ \\
Polar filament length & $12.82 \pm 2.33(103)$ & - \\
Spore width & $3.52 \pm 0.33(227)$ & $5.59 \pm 0.39(283)$ \\
Polar capsule length & - & $4.45 \pm 0.35(257)$ \\
Polar capsule width & - & $2.40 \pm 0.31(257)$
\end{tabular}

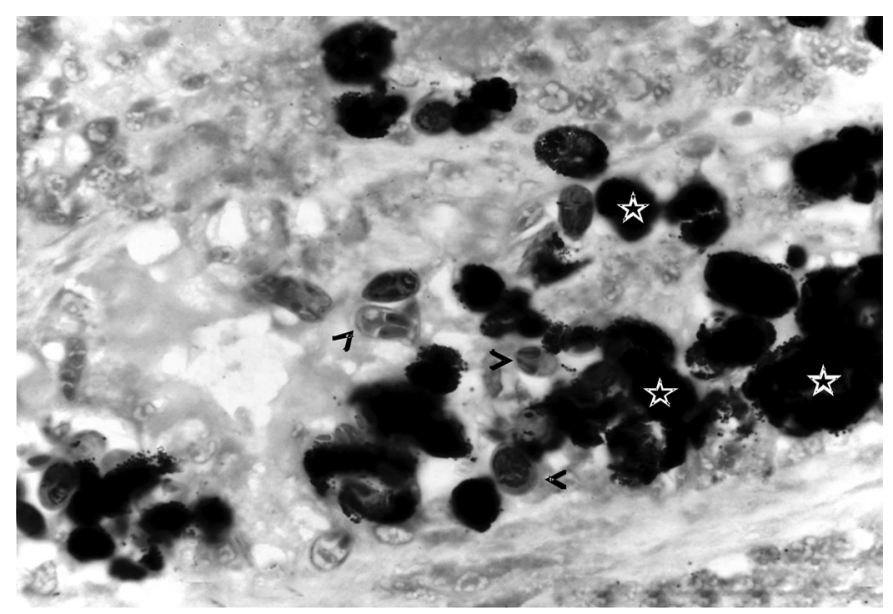

Fig.4. Spores of Myxobolus sp. (arrowhead) and melanomacrophages (star) in the kidney of Piaractus mesopotamicus. ZN, Bar = $10 \mu \mathrm{m}$.

\section{DISCUSSION}

The epithelial hyperplasia observed represented a nonspecific organic defense response, and in this case, it may have been a consequence of the presence of plasmodia. This cell proliferation occurred in the gill-coating epithelium, between the secondary lamellae, and filled the interlamellar space, thereby promoting fusion and impairing gas and ion exchanges (Martins et al. 1997, 1999a,b). The edema may also have resulted from the presence of the plasmodia, particularly if the plasmodia were located in the lumina of vessels,which would cause blood flow obstruction and increased hydrostatic pressure, and would promote emptying of fluid accumulations from the subepithelial space. However, poor water quality due to excesses of particulate material and/or pollutants also causes subepithelial edema, and this edema protects the integrity of the sinusoid capillaries in that it keeps them further away from the aggressive agent. The consequence of the edema is similar to that of hyperplasia, as previously observed in Piaractus mesopotamicus (Martins et al. 1997, 1999a,b) and in Astyanax altiparanae (Barassa et al. 2003).

In the kidneys, infiltration by melanomacrophages and formation of a thin connective capsule around the spores 
are characteristic defense responses of the organism. These structures were present around and inside the renal tubules and interstitial tissue, as also described by Molnar et al. 2009. Presence of parasites in the glomerular capillaries may cause reduced blood flow and diminished offer of oxygen and nutrients to the tissues, thus producing necrosis and inflammation. This leads to increased cellularity in the glomerular tuft caused by the influx of leukocytes that are attracted by the necrotic material and, consequently, reduction of the Bowman space. Decreased renal tubule lumen size occurs because of the cellular edema, and necrosis of the hematopoietic tissue may occur, accompanied by fibrosis, as also observed by other authors (Dey et al. 1988, Roberts 2001).

The melanomacrophage infiltrate and connective capsule around the spores are host defense responses that attempt to destroy or isolate the parasite (Molnár et al. 2009). Chronic infection due to myxosporidians may give rise to severe lesions such as necrosis (Molnár \& Kovács-Gayer 1985, Dycová \& Lom 1988). According to Martins et al. (1999a), the presence of Myxobolus sp. may cause damage depending on the host response capacity and/or the virulence of the parasite involved. The findings from this observation suggest that these parasites are potentially pathogenic and that the severity of the disease depends on the parasite load, for respiratory and renal function to be compromised.

The parasites identified in the gills presented morphology and characteristics compatible with the myxozoan Henneguya sp., with a fusiform spore body formed by two valves with two polar capsules (Lom \& Dyková 2006). These structures were not measured because of lack of detailing, since these were young spores (Adriano et al. 2005).

Ziehl-Neelsen staining on the histological sections made it possible to view the parasite spores. In mycobacteria, this stain is produced by the high lipid content of the cell wall. When treated with phenicated fuchsine, the cell walls stain red and this color persists even after using strong acid-alcohol color-removal solutions, thereby constituting a means of differentiating these bacteria. The spore wall composition is likely to be similar.

Azevedo et al. (2010) morphologically classified myxosporidians of the genus Henneguya sp. according to the presence of two polar filaments that were in continuity with the basal portion of the spore body. Thus, comparison of the measurements of the protozoon described in the present study with those of Henneguya sp., as described by Azevedo et al. (2010), plus the fact that the findings relate to the same species of fish and same organ, suggests that the forms described here are of the species $H$. piaractus (Martins et al. 1997).

In comparing Myxobolus sp. $(8.94 \pm 0.82 \mu \mathrm{m})$ in the present observations with $M$. inaequus $(19.8 \mu \mathrm{m})$ (Kent \& Hoffman 1984), M. maculatus $(21.0 \mu \mathrm{m})$ (Casal et al. 2002), M. serrasalmi (7.0-9.5 $\mu \mathrm{m})$ (Walliker 1969) and M. cuneus $(10.0 \pm 0.6 \mu \mathrm{m})$ (Adriano et al. 2006), morphological similarities were seen, but not biometric ones. In relation to $M$. inaequus and M. maculatus, there were differences in the morphology of the filaments of the polar capsules. In comparison with $M$. cuneus, there were morphological and biometric similarities, suggesting that the parasites found here was possibly $M$. cuneus. Although not present in the gills as observed by Adriano et al. (2006) but, rather, in the kidneys, it can be supposed that this species may reach any organ through the bloodstream. All the parasites mentioned are included among the myxosporidians that parasitize freshwater fish in South America.

Ziehl-Neelsenstaining for histological sections was shown to be efficient for morphologically identifying the spores of myxosporidians in a mature state, since it stained the exoskeleton, polar capsules and polar filament. It was useful for making the histopathological diagnosis of myxosporidiosis at the genus level.

Acknowledgements.- To the Research Support Foundation of the State of São Paulo (FAPESP, Procedural No. 2009/17640-7).

\section{REFERENCES}

Adriano E.A., Arana S. \& Cordeiro N.S. 2005. An ultrastructural and histopathological study of Hennguya pellucida n. sp. (Myxosporea: Myxobolidae) infecting Piaractus mesopotamicus (Characidae) cultivated in Brazil. Parasite. 12:221-227.

Adriano E.A., Arana S. \& Cordeiro N.S. 2006. Myxobolus cuneus n. sp. (myxosporea) infecting the connective tissue of Piaractus mesopotamicus (Pisces: Characidae) in Brazil: Histopathology and ultrastructure. Parasite 13:137-142.

Azevedo C., Marques D.K.S., Casal G., Amaral C.M.C., Silva E.V., Matos P. \& Matos E. 2010. Ultrastructural re-description of Henneguya piaractus (Myxozoa), a parasite of the fresh water fish Piaractus mesopotamicus (Teleostei, Characidae) from the Paraguai river, Brazil. Acta Protozool. 49:115-120.

Barassa B., Cordeiro N.S. \& Aranha S. 2003. A new specie of Henneguya sp., a gill parasite of Astyanax altiparanae (pisces:characidae) from Brazil, with comments on histopathology and seasonality. Mem. Inst. Oswaldo Cruz 98:761-765.

Campos M.C., Moraes E.R.J. \& Moraes R.F. 2008. Histopatologia de fígado, rim e baço de Piaractus mesopotamicus, Prochilodus lineatus e Pseudoplatystoma fasciatum parasitados por myxosporídios, capturados no Rio Aquidauana, Mato Grosso do Sul, Brasil. Braz. J. Vet. Parasitol. 17:200-205.

Campos M.C., Moraes E.R.J. \& Moraes R.F. 2011. Histopathology of gills of Piaractus mesopotamicus (Holmberg, 1887) and Prochilodus lineatus (Valenciennes, 1836) infested by monogenean and myxosporea, caugth in Aquidauana River, State of Mato Grosso do Sul, Brazil. Revta. Bras. Parasitol. Vet. 20:67-70.

Casal G., Matos E. \& Azevedo C. 2002. Ultrastructural data on the spore of Myxobolus maculatus n. sp. (phylum Myxozoa), parasite from the Amazonian fish Metynnis maculates (Teleostei). Dis. Aquat. Org. 51:107-111.

Dey R.K., Kuma D. \& Mishra B.K. 1988. Tissue level reactions in the Indian major Carp. Catla catla (Ham.), due to Myxobolus sp. infection. Asian Fisheries Science 1:117-122.

Ducati R.G., Basso L.B. \& Santos D.S. 2005. Micobactérias, p.409-421. In: Trabulsi L.R. \&. Alterthum F. (Eds), Microbiologia. $4^{\text {th }}$ ed. Atheneu, São Paulo.

Eszterbauer E., Marton S., Letenyei M., Rácz O.Z., Letenyei M. \& Molnár K. 2006. Morphological and genetic differences among actinosporean stages of fish-parasitic myxosporeans (Myxozoa): Difficulties of species identification. Syst. Parasitol. 65:97-114.

Kent M.L. \& Hoffman G.L. 1984. Two new species of Myxozoa, Myxobolus inaequus sp. n. and Henneguya theca sp. n. from the brain of a South American knife fish, Eigemannia virescens (V.). J. Protozool. 31:91-94.

Lom J. \& Dyková I. 2006. Myxozoan genera: definition and notes on taxonomy, life-cycle terminology and pathogenic species. Folia Parasitol. $53: 1-36$ 
Lom J. \& Dyková I. 1992. Protozoan Parasites of Fishes. Elsevier, Amsterdam, p.159-235.

Lom J. \& Noble E.R. 1984. Revised classification of the class Myxosporea bütschli 1881. Folia Parasitologica 3:193-205.

Martins M.L., Souza V.N., Moraes J.R.E., Moraes F.R., Costa A.J. \& Rocha U.F. 1997. Pathology and behaviour effects associated with Henneguya sp. (Myxozoa: Myxobolidae) infections of captive pacu Piaractus mesopotamicus in Brazil. J. World Aquacult. Soc. 28(3):297-300.

Martins M.L., Souza V.N., Moraes J.R.E., Moraes F.R. \& Costa A.J. 1999a. Comparative evaluation of the susceptibility of cultivated fishes to the natural infection with myxosporean parasites an tissues changes in the host. Revta. Bras. Biol. 59(2):263-269.

Martins M.L., Souza V.N., Moraes J.R.E. \& Moraes F.R. 1999b. Gill infection of Leporinus macrocepahlus Garavelo et Britiski, 1988 (Osteichthyes: Anostomidae) by Henneguya leporinicola n. sp. (Myxozoa: Myxobolidae): Description, histopathology and treatment. Revta Bras. Biologia 59(3):527-534.

Martins M.L., Moraes F.R., Fujimoto R.Y.. Onaka E.M., Nomura D.T., Silva C.A.H. \& Schalch S.H.C. 2000. Parasitic infections in cultivated freshwater fishes a survey of diagnosticated cases from 1993 to 1998. Revta. Bras. Parasitol. Vet. 9(1):23-38.

Martins M.L., Onaka E.M., Moraes F.R., Bozzo F.R., Paiva A.M.F.C. \& Gonçalves A. 2002. Recent studies on parasitic infections of freshwater cultivated fish in the state of São Paulo, Brazil. Acta Scient. 24(4):981-985.

Meyers T.R., Sawyer T.K. \& Madean A. 1977. Henneguya sp. (Cnidospora-
Myxosporea) in the heart of bluefish, Pomatomus salatrix. J. Parasitol. 63:890-896

Molnár K. \& Kovács-Gayer L. 1985. The pathogenicity and development within the host fish of Myxobolus cyprinid Doflein. Parasitology 90:5763.

Molnár K., Eszterbauer E., Marton S.Z., Cech G. \& Szekely CS. 2009. Мухоbolus erythrophthalmi sp. n. and Myxobolus shaharomae sp. n. (Myxozoa: Myxobolidae) from the internal organs of rudd, Scardinius erythrophthalmus (L.), and bleak, Alburnus alburnus (L.). J. Fish Dis. 32:219-231.

Moraes F.R. \& Martins M.L. 2004. Condições predisponentes e principais enfermidades de teleósteos cultivados, p.343-386. In: Cyrino J.E.P., Urbinati E.C., Fracalossi D.M. \& Castagnolli N. (Eds),Tópicos Especiais em Piscicultura de Água Tropical Intensiva. TecAr, São Paulo.

Roberts R. 2001. Fish Pathology, p. 96. $3^{\text {rd }}$ ed. W.B, Saunders, Philadelphia.

Sardella H.N., Trinchero L.J. \& Manca A.E. 1987. Efecto del deterioro producido por mixosporídios de la espécie Kudoa rosenbuschi em la musculatura de Merluccius hubbsi. Revta Invest. Des. Pesq. 7:105-112.

Shalch S.H.C. \& Moraes F.R. 2005. Distribuição sazonal de parasitos branquiais em diferentes espécies de peixes em pesque-pague do município de Guariba SP, Brasil. Revta Bras. Parasitol. Vet. 14(4):141-146.

Tavares-Dias M., Moraes F.R., Martins M.L. \& Kronka S.N. 2001. Fauna parasitária de peixes oriundos de pesque-pague de município de Franca, São Paulo, Brasil. II. Metazoários. Revta Bras. Zool. 18(1):81-95.

Walliker D. 1969. Myxosporidea of some Brazilian freshwater fishes. J. Parasitol. 55:942-948. 